\title{
Control of extracellular matrix remodelling within ovarian tissues: localization and regulation of gene expression of plasminogen activator inhibitor type- 1 within the ovine corpus luteum
}

\author{
G. W. Smith ${ }^{1}$, P. C. Gentry ${ }^{1}$, B. Bao ${ }^{1}$, D. K. Long $^{1}$, R. M. Roberts ${ }^{1,2}$ \\ and M. F. Smith ${ }^{1 *}$ \\ Department of ${ }^{1}$ Animal Science and ${ }^{2}$ Biochemistry, University of Missouri, Columbia, MO 65211, USA
}

\begin{abstract}
Extensive extracellular matrix remodelling occurs within the lifespan of the corpus luteum, particularly during corpus luteum formation and regression. A major mechanism for the regulation of extracellular matrix remodelling is via local production of specific proteinase inhibitors, such as the serine proteinase inhibitor plasminogen activator inhibitor type-1 (PAI-1). The objective of the present study was to characterize the localization, ontogeny and regulation of PAI-1 expression within ovine corpora lutea. Urokinase binding activity was detected within medium conditioned by ovine luteal cells. Production of PAI-I by ovine luteal cells was confirmed by immunoprecipitating it from labelled proteins in culture medium. mRNA encoding PAI-1 was present within developing (day 3), mature (day 10) and regressing ( $30 \mathrm{~h}$ after prostaglandin $\mathrm{F}_{2 \alpha}$ injection on day 10 after the onset of oestrus) corpora lutea as demonstrated by in situ hybridization. The ontogeny of PAI-I mRNA expression was characterized within corpora lutea collected on days 3, 7, 10, 13 and 16 after the onset of oestrus ( $n=4,4,4,3$ and 4, respectively). Expression of PAI-I mRNA did not differ during the luteal phase $(P=0.06)$, although a trend for an increase in the amount of PAI-1 mRNA was observed on day 16. Expression of PAI-1 mRNA was also examined during luteal regression in corpora lutea collected $0,6,12,24$ and $36 \mathrm{~h}$ after injection of prostaglandin $\mathrm{F}_{2 \alpha}$ on day 10 after the onset of oestrus ( $n=4$ at each time). Relative PAI- 1 mRNA concentrations changed significantly during luteolysis induced by prostaglandin $F_{2 \alpha}$ $(P=0.0002)$. Administration of prostaglandin $F_{2 \alpha}$ resulted in a transient sevenfold increase in PAI-1 mRNA $6 \mathrm{~h}$ after injection $(P=0.0001)$ but by $12 \mathrm{~h}$ the amounts had returned to values similar to those detected on day 10. We conclude that PAI-I is a major secretory product of ovine luteal cells and that a transient increase in PAI-1 mRNA occurs during luteolysis induced by prostaglandin $\mathrm{F}_{2 \alpha}$. PAI-1 probably plays a key local role in the control of extracellular proteolysis during the luteal phase.
\end{abstract}

\section{Introduction}

Changes in the extracellular matrix have profound effects on many complex biological processes, including cell migration, cell proliferation, cell differentiation and gene expression (Getzenberg et al., 1990). Two families of enzymes involved in the degradation of the extracellular matrix include the metalloproteinases and the plasminogen-activator-plasmin system, and both contribute to the directed proteolysis and tissue remodelling that occurs during ovulation and subsequent development of the corpus luteum (Espey and Lipner, 1994; Smith et al., 1994a).

The plasminogen activators tissue plasminogen activator $(\mathrm{tPA})$ and urokinase ( $\mathrm{UPA}$ ) are serine proteinases responsible for

* Correspondence and reprint requests.

Revised manuscript received 26 February 1997 cleavage of the ubiquitous zymogen plasminogen into its active form plasmin, which is the major enzyme responsible for fibrinolysis (Hart and Rehemtulla, 1988). In addition to its fibrinolytic capacity, plasmin can activate several metalloproteinases involved in degradation of the extracellular matrix (Mignatti et al., 1986) and can directly hydrolyse the extracellular matrix glycoproteins laminin and fibronectin (Tryggvason et al., 1987).

A mechanism for regulation of extracellular proteolysis catalysed by the plasminogen-activator-plasmin system is by the secretion of specific plasminogen activator inhibitors, such as plasminogen activator inhibitor type-1 (PAI-1). PAI-1 is a glycoprotein of approximately $54000 M_{\mathrm{r}}$ (Van Mourik et al., 1984) belonging to the serpin family of proteinase inhibitors (Roberts et al., 1995) and is an efficient inhibitor of both tPA and uPA (Thorsen $e$ al., 1988). PAI-I can regulate extracellular matrix remodelling since the co-culture of a transfected mouse 
$\mathrm{L}$ cell line expressing high amounts of PAI-I with cell lines actively expressing $\mathrm{PPA}$ or $\mathrm{UPA}$ prevents the breakdown of the extracellular matrix (Cajot et al., 1990). Endothelial cells are thought to be the source of most PAI-1 in serum (Hart and Rehemtulla, 1988), although mRNA encoding PAI-1 expression has also been detected within numerous cells of the reproductive system, including both thecal-interstitial cells and granulosa cells of rodent follicles (Chun et al., 1992; Peng et al., 1993) and rat decidual cells (Bacharach et al. 1992).

The localization and hormonal regulation of the plasminogen activators and their inhibitors within follicular tissue during the periovulatory period has been extensively studied (reviewed by $\mathrm{Ny}$ et al., 1993). However, the potential contribution of PAI- 1 to the regulation of the plasminogen activator system in corpora lutea during the luteal phase is not completely understood. Therefore, the objectives of the present experiments were to characterize the localization, ontogeny and regulation of PAI-1 expression within the ovine corpus luteum.

\section{Materials and Methods}

\section{Animal care}

All procedures described below that used animals were approved by the University of Missouri Animal Care and Use Committee (Protocol 2308).

\section{Materials}

The RNA transcription kit and restriction endonucleases were obtained from Stratagene (La Jolla, CA). ${ }^{32} \mathrm{P},{ }^{35} \mathrm{~S}$ and ${ }^{3} \mathrm{H}$ radionuclides were obtained from New England Nuclear (Boston, MA). Biotrans nylon membrane was obtained from ICN Biomedicals (Irvine, CA). The multiprime DNA labelling kit was obtained from Ambion (Austin, TX). XAR-5 film and NTB-2 emulsion were purchased from Eastman Kodak (Rochester, NY). RNA molecular mass markers were from Boehringer Mannheim (Indianapolis, IN). Prostaglandin $F_{2 \alpha}$ $\left(\mathrm{PGF}_{2 u}\right.$ ) was obtained from Upjohn (Kalamazoo, MI). Deoxyribonuclease I and protein-A-Sepharose were purchased from Sigma Chemical Co. (St Louis, MO). Type IV collagenase was from Worthington Biochemicals (Freehold, NJ). Cell culture media were from the University of Missouri Cell Culture Core facility. Human urokinase (UPA) was from Calbiochem (San Diego, CA). $\mathrm{Na}^{125}$ I was from Amersham (Arlington Heights). Iodogen was from Pierce (Rockford, IL). All other reagents were purchased from Fisher Scientific (St Louis, MO).

\section{Collection of corpora lutea}

Oestrus was synchronized in ewes of mixed breed $(n=61)$ by injecting them with $15 \mathrm{mg}$ PGF $_{2 \alpha}$. Ewes were observed for oestrous behaviour twice a day with vasectomized rams (day $0=$ onset of oestrus). For immunoprecipitation studies, corpora lutea were collected on day 7 after oestrus ( $n=4$ animals) and processed for enzymatic dissociation. For collection of medium conditioned by ovine luteal cells, corpora lutea were collected on days 9-11 after oestrus and also processed for enzymatic dissociation ( $n=9$ animals). For isolation of RNA, ovaries containing corpora lutea were collected on days $3,7,10,13$ and 16 after oestrus ( $n=4,4,4,3$ and 4, respectively) and at 0 , $6,12,24$ and $36 \mathrm{~h}$ after i.m. injection of $15 \mathrm{mg} \mathrm{PGF}{ }_{2 u}$ on day 10 after oestrus ( $n=4$ at each time). Jugular venous samples were collected just before injection of $\mathrm{PGF}_{2 u}$ and just before ovariectomy to verify the initiation of luteal regression via serum progesterone assay (Keisler and Keisler, 1989). Corpora lutea were also collected on days 3 and 10 after oestrus and $30 \mathrm{~h}$ after the $\mathrm{PGF}_{2 \alpha}$ injection ( $n=3$ per group), excised surrounded by stromal tissue, and processed for in situ hybridization.

\section{Detection of urokinase binding activity}

Corpora lutea were dispersed and mixed luteal cells were cultured as described by Fitz et al. (1982) and Smith et al. (1993) ( $n=3$ replicates). Briefly, $1 \times 10^{7}$ cells were plated into $75 \mathrm{~cm}^{2}$ flasks and incubated overnight $\left(38^{\circ} \mathrm{C}, 5 \% \mathrm{CO}_{2}\right)$ in Dulbecco's Modified Eagle's Medium/Ham's F12 (DMEM/F12) containing $10 \%$ ram serum to allow for attachment. After attachment, cells were washed extensively (3-4 times) and cultured under serum-free conditions in DMEM/F12. Conditioned media were collected once a day for 3 days, pooled within replicate, dialysed, and the protein concentration was determined (Smith et al. 1985). Luteal cells were collected from a minimum of three ewes for each replicate.

Purified human uPA was iodinated with $\mathrm{Na}\left[{ }^{125} \mathrm{I}\right]$ to a specific activity of $196 \mu \mathrm{Ci}_{\mathrm{gg}}{ }^{-1}$ by the iodogen method, as described by Li and Roberts (1994). Approximately $10 \mu \mathrm{g}$ ovine luteal protein was incubated with $260 \mathrm{pg}{ }^{125} \mathrm{I}$-labelled uPA in the presence or absence of $200 \mathrm{ng}$ unlabelled uPA at $37^{\circ} \mathrm{C}$ for $1 \mathrm{~h}$. Control reactions were also conducted in which $\left.{ }^{125} \mathrm{I}\right] \mathrm{uPA}$ was preincubated in the presence of $10 \mathrm{mmol}$ phenylmethylsulfonyl fluoride (PMSF) $1^{-1}$ for $1 \mathrm{~h}$ at $37^{\circ} \mathrm{C}$ before luteal protein was added. After incubation, samples of the reaction mixtures were added to an equal volume of $2 \times \mathrm{SDS}$ loading buffer ( $x=50 \mathrm{mmol}$ Tris $\mathrm{I}^{-1}, \mathrm{pH} 6.8,2 \%(\mathrm{w} / \mathrm{v}) \mathrm{SDS}, 0.1 \%(\mathrm{w} / \mathrm{v})$ bromophenol blue and $10 \%(\mathrm{v} / \mathrm{v})$ glycerol) containing $2 \%(\mathrm{v} / \mathrm{v})$ mercaptoethanol, heated at $95^{\circ} \mathrm{C}$ for $3 \mathrm{~min}$, and analysed by SDS-PAGE and autoradiography.

\section{Immunoprecipitation}

Corpora lutea collected on day 7 after oestrus were enzymatically dispersed (Smith et al., 1993). Approximately $3 \times 10^{6}$ mixed luteal cells were plated into $25 \mathrm{~cm}^{2}$ flasks and incubated overnight $\left(38^{\circ} \mathrm{C}, 5 \% \mathrm{CO}_{2}\right)$ in DMEM/FI2 containing $10 \%$ ram serum. After they had attached, cells were washed extensively and cultured in methionine- and leucinefree Minimal Essential Medium containing $150 \mu \mathrm{Ci}$ $\mathrm{L}-\left[{ }^{35} \mathrm{~S}\right]$ methionine $\mathrm{ml}^{-1}$ and $\left.30 \mu \mathrm{Ci} \mathrm{L-}-{ }^{3} \mathrm{H}\right]$ leucine $\mathrm{ml}^{-1}$ for $6 \mathrm{~h}$. Culture media containing secretory proteins were then collected and dialysed extensively before analysis.

Immunoprecipitation of PAI- 1 from luteal cell culture medium was conducted according to standard procedures (Sambrook et al., 1989). Approximately 250000 c.p.m. ${ }^{35} \mathrm{~S}$ labelled and ${ }^{3} \mathrm{H}$-labelled luteal secretory proteins were precleared overnight with $\mathrm{I} \mu \mathrm{l}$ normal rabbit serum at $4^{\circ} \mathrm{C}$, and nonspecific immunoglobulin-protein complexes were removed 
with Protein-A-Sepharose. The remaining secretory proteins were then incubated with $1 \mu \mathrm{l}$ rabbit anti-human PAI-I serum (Schleef et al., 1990; serum kindly provided by D. J. Loskutoff, Scripps Research Institute, La Jolla, CA) or I $\mu$ l normal rabbit serum in a total volume of $0.5 \mathrm{ml} \mathrm{NET}$-gel buffer $(50 \mathrm{mmol}$ Tris $1^{-1}(\mathrm{pH} 7.5), 150 \mathrm{mmol} \mathrm{NaCl} \mathrm{l}{ }^{-1}, 0.1 \%(\mathrm{v} / \mathrm{v})$ Nonidet P-40, $1 \mathrm{mmol}$ EDTA $^{-1}, 0.25 \%(\mathrm{w} / \mathrm{v})$ gelatin, $0.02 \%(\mathrm{w} / \mathrm{v})$ sodium azide) overnight at $4^{\circ} \mathrm{C}$. Immunoreactive protein was precipitated with Protein-A-Sepharose, washed three times with NET-gel buffer and released from the immunoglobulinProtein-A-Sepharose complex by boiling for $3 \mathrm{~min}$ in $1 \times$ SDS loading buffer containing $100 \mathrm{mmol}$ dithiothreitol (DTT) $\mathrm{l}^{-1}$. Samples were then analysed by SDS-PAGE and fluorography.

\section{Northern blot analysis}

Total cellular RNA was isolated using guanidinium thiocyanate and caesium chloride, as described by Chirgwin et al. (1979). Approximately $15 \mu \mathrm{g}$ RNA (collected from individual corpora lutea) was subjected to electrophoresis through agarose-formaldehyde gels. RNA was then transferred by capillary action to nylon membranes. Filters were subjected to northern blot analysis (Smith et al., 1994b) using a random prime labelled (Sambrook et al., 1989) bovine PAI-1 cDNA (Mimuro et al., 1989; cDNA kindly provided by D. J. Loskutoff, Scripps Research Institute, La Jolla, CA) and exposed to XAR-5 film at $-80^{\circ} \mathrm{C}$. Filters were then stripped and rehybridized with an ovine glyceraldehyde-3-phosphate dehydrogenase (G3PDH) cDNA (Smith et al., 1996). The size of mRNA transcripts detected was determined based on the relative migration of RNA molecular mass markers.

\section{Dot blot analysis}

RNA samples ( $5 \mu \mathrm{g}$ per sample) from individual animals were blotted in triplicate on to nylon membranes. Filters were

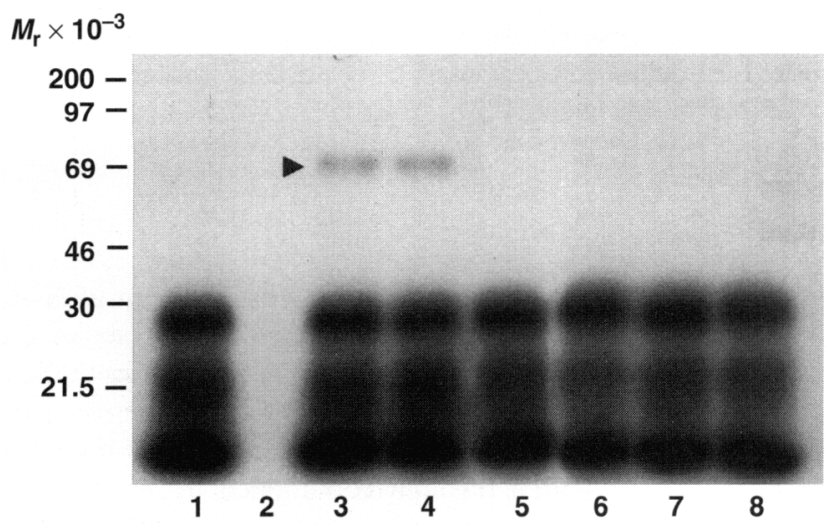

Fig. 1. Detection of urokinase (uPA) binding activity within medium conditioned by ovine luteal cells. Ovine luteal proteins were incubated with $\left({ }^{125} \mathrm{I}\right] \mathrm{uPA}$ in the presence or absence of excess cold uPA, or in the presence of $\left[{ }^{125} \mathrm{Ij} \mathrm{PPA}\right.$ that had been preincubated in the presence of $10 \mathrm{mmol}$ PMSF $\mathrm{I}^{-1}$, and subsequently analysed by SDS-PAGE and autoradiography. Lane $1,\left[{ }^{125} \mathrm{I}\right] \mathrm{uPA}$ alone; lane 2, blank; lanes 3, 4, $\left[{ }^{125} \mathrm{I}\right] \mathrm{uPA}+10 \mu \mathrm{g}$ luteal proteins; lanes $5,6,\left[{ }^{125} \mathrm{I}\right] \mathrm{uPA}+10 \mu \mathrm{g}$ luteal proteins + excess cold uPA, and; lanes $7,8,\left[{ }^{125} \mathrm{l}\right] \mathrm{uPA}$ preincubated with $10 \mathrm{mmol} \mathrm{PMSF}^{-1}+10 \mu \mathrm{g}$ luteal proteins.

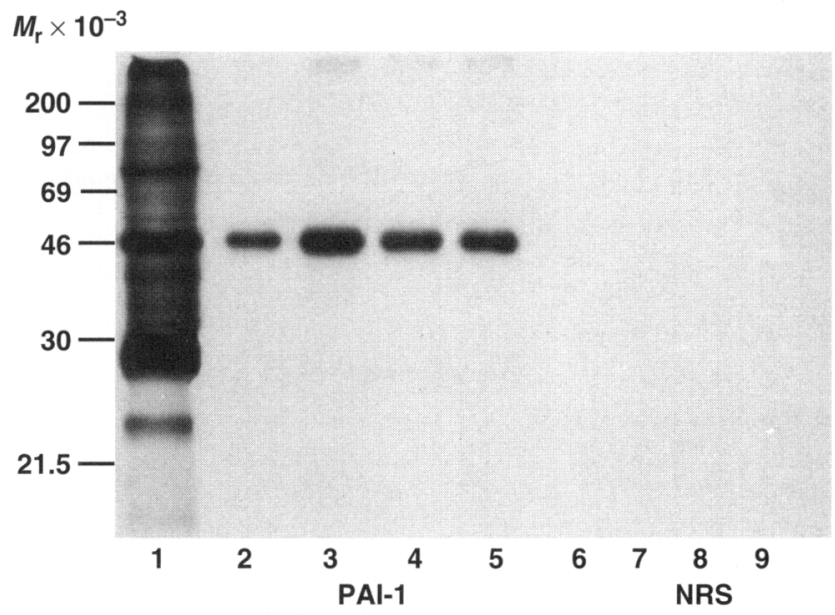

Fig. 2. Immunoprecipitation of plasminogen activator inhibitor type-1 (PAI-1) from ovine luteal cell culture medium. Fluorograph of a one-dimensional SDS-polyacrylamide gel containing ${ }^{35}$ S-labelled and ${ }^{3} \mathrm{H}$-labelled luteal cell secretory proteins (lane 1 ) and proteins immunoprecipitated with a rabbit anti-human PAI-1 serum (lanes 2-5) or with a normal rabbit serum (NRS) control (lanes 6-9; $n=4$ replicates from separate animals).

baked at $80^{\circ} \mathrm{C}$ for $2 \mathrm{~h}$ and then prehybridized, hybridized and exposed to XAR-5 film as described for northern blots. Adjustments for differences in loading were made by stripping filters and rehybridizing to a ${ }^{32}$ P-labelled ovine G3PDH cDNA (Smith et al., 1996). Images were captured from film with a 400 d.p.i. hand-held scanner (Logitech, Fremont, CA) and the intensity of hybridization signals was evaluated using an image analysis programme ('Sigma Scan/Image', Jandel Scientific, San Rafael, CA). Relative amounts of mRNA encoding PAI-1 were adjusted and expressed as units of PAI-1 mRNA per unit of G3PDH mRNA. Expression of G3PDH mRNA did not differ either during the luteal phase or during luteal regression $(P>0.1$; data not shown).

\section{In situ hybridization}

After ovariectomy, tissue samples were immediately mounted in embedding medium, frozen over liquid nitrogen and stored at $-80^{\circ} \mathrm{C}$ until sectioned. Sections $12 \mu \mathrm{m}$ thick were mounted on to gelatin-coated slides, fixed in $4 \%(\mathrm{w} / \mathrm{v})$ formalin, acetylated and dehydrated before hybridization. Hybridizations were carried out on serial sections for each probe on each tissue sample and performed in duplicate.

In situ localization of PAI-I mRNA was carried out using ${ }^{35}$ S-labelled antisense cRNA probes generated from a $916 \mathrm{bp}$ bovine PAI-1 cDNA corresponding to nucleotides 19-935 of the bovine PAI-1 cDNA (Mimuro et al., 1989). The sense cRNA was used as a negative control. Complementary RNA probes were subjected to limited alkaline hydrolysis before hybridization (Chesselet, 1990). Hybridization and washing conditions were identical to those described by Smith et al. (1995). After drying, slides were dipped in NTB-2 emulsion, developed 14 days later and subsequently counterstained with haematoxylin and eosin to assess morphology. 
(a)

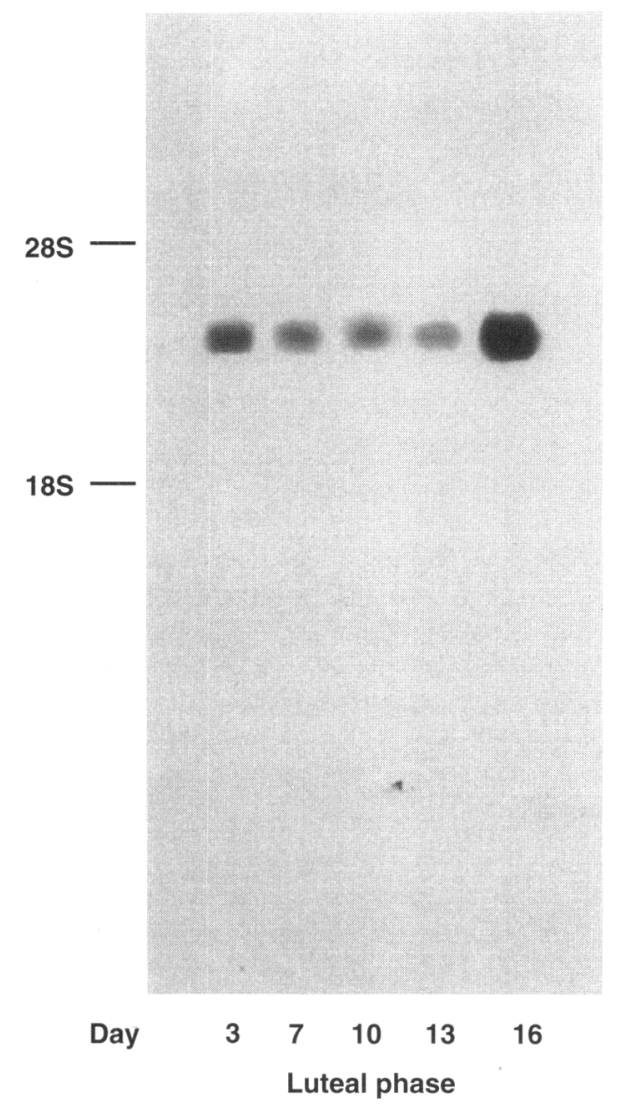

G3PDH - (b)

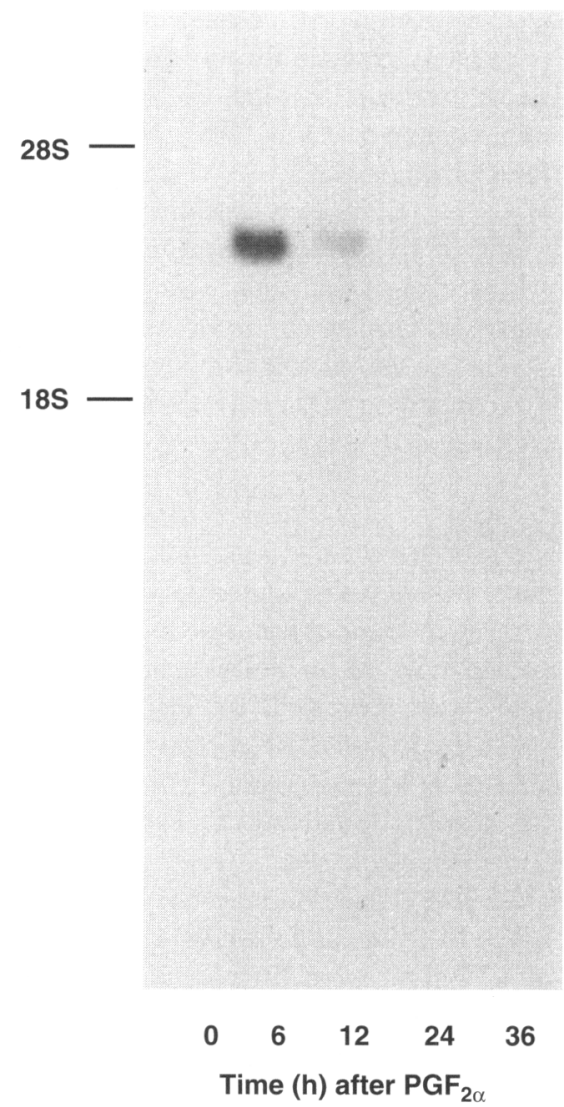

G3PDH -

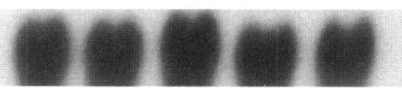

Fig. 3. Northern analysis of expression of mRNA encoding plasminogen activator inhibitor type-1 (PAI-1). (a) Representative northern blot of total cellular RNA samples ( $15 \mu \mathrm{g}$ per lane) isolated from ovine copora lutea collected on days $3,7,10,13$ and 16 after oestrus (lanes $1-5$ ). Filters were probed with a ${ }^{32}$ P-labelled bovine PAI- 1 cDNA and exposed to XAR-5 film for 10 days. Filters were then stripped and reprobed with a ${ }^{32} \mathrm{P}$-labelled ovine glyceraldehyde-3-phosphate dehydrogenase (G3PDH) cDNA. (b) Representative northern blot of total cellular RNA samples (15 $\mu$ g per lane) isolated from ovine corpora lutea collected $0,6,12,24$ and $36 \mathrm{~h}\left(n=4\right.$ each) after prostaglandin $\mathrm{F}_{2 u}\left(\mathrm{PGF}_{2 \alpha}\right)$ injection on day 10 after oestrus (lanes 1-5). Filters were probed with a ${ }^{32}$ P-labelled bovine PAI-I cDNA and exposed to XAR-5 film for $36 \mathrm{~h}$. Filters were then stripped and reprobed with a ${ }^{32} \mathrm{P}$-labelled ovine G3PDH $c D N A$.

\section{Statistical analysis}

Differences in concentrations of PAI- 1 and G3PDH mRNA expressed by ovine corpora lutea were determined by one-way analysis of variance. Individual comparisons of mean RNA concentrations were performed when appropriate using Fisher's protected least significant difference test.

\section{Results}

Identification of PAI-1 as a major secretory product of ovine luteal cells

Urokinase binding activity was detected within medium conditioned by ovine luteal cells. When analysed under reduc- ing conditions, both subunits of activated two-chain uPA are detectable (Fig. 1, lane 1), although slight radiolysis of the ${ }^{125}$ I-labelled urokinase is also evident. The larger subunit (about $30000 M_{\mathrm{r}}$ ) present in lane 1 corresponds to the catalytic subunit of uPA, the subunit that can be bound by inhibitor. Proteins present within medium conditioned by ovine luteal cells formed a complex of approximately $70000 M_{\mathrm{r}}$ with $\left[{ }^{125}\right.$ I] uPA (Fig. 1, lanes 3, 4). The formation of this complex was inhibited by incubation in the presence of an approximately 1000-fold excess of unlabelled uPA (Fig. 1, lanes 5, 6) or by preincubation of $\left[{ }^{125} \mathrm{I}\right] \mathrm{uPA}$ in the presence of $10 \mathrm{mmol}$ PMSF $1^{-1}$ (Fig. 1, lanes 7,8 ).

Immunoprecipitation analysis of ${ }^{35} \mathrm{~S}$-labelled and ${ }^{3} \mathrm{H}$-labelled luteal cell secretory proteins verified that PAI-I is a major secretory product of cultured ovine luteal cells. A radiolabelled 
protein of approximately $56000 M_{\mathrm{r}}$ was precipitated with a polyclonal antiserum generated against human PAI-1, and was absent when normal rabbit serum was used (Fig. 2).

\section{Ontogeny of expression of $m R N A$ encoding PAI-1 during the luteal phase}

Expression of mRNA encoding PAI- 1 was evaluated within corpora lutea collected on days $3,7,10,13$ and 16 of the oestrous cycle by northern and dot blot analysis. A single $3.6 \mathrm{~kb}$ PAI-I mRNA species was detected within all luteal samples examined (Fig. 3a). Expression of mRNA encoding PAI-I did not vary over the luteal phase $(P=0.06)$, although a trend for increased PAI-I mRNA concentrations on day 16 was observed (Fig. 4a).

\section{Expression of PAI-1 mRNA during PGF ${ }_{2 a}$ induced luteolysis}

Because a trend for increased expression of mRNA encoding PAI-I was observed within regressing corpora lutea (on day 16 after oestrus), expression of PAI-1 mRNA within corpora lutea collected at precise times during $\mathrm{PGF}_{2 \alpha}$-induced luteolysis $(0,6$, 12,24 and $36 \mathrm{~h}$ after $\mathrm{PGF}_{2 \alpha}$ injection on day 10) was followed (Fig. 3b). Relative concentrations of PAI-1 mRNA changed significantly during $\mathrm{PGF}_{2 \alpha}$-induced luteolysis $(P=0.0002)$. Specifically, administration of $\mathrm{PGF}_{2 \alpha}$ resulted in a transient sevenfold increase in expression of PAI-1 mRNA by $6 \mathrm{~h}$ after injection (Fig. $4 \mathrm{~b} ; P=0.0001$ ). Relative concentrations of PAI-1 mRNA returned to values similar to that in uninjected control corpora lutea on day 10 by $12 \mathrm{~h}$ after injection (Fig. $4 \mathrm{~b}$ ). An assay of serum progesterone verified that all animals injected with $\mathrm{PGF}_{2 \alpha}$ responded with a decrease in the concentration of progesterone in the serum (data not shown).

In situ localization of $m R N A$ encoding PAI-1 within ovine luteal tissue

mRNA encoding PAI-I was heavily concentrated within ovine corpora lutea collected on days 3 and 10 after oestrus and within corpora lutea collected $30 \mathrm{~h}$ following $\mathrm{PGF}_{2 u}$ injection on day 10 (Fig. 5b, e and h, respectively; $n=3$ animals each). Significant hybridization was not detected within the adjacent ovarian stroma (Fig. 5b, e and h). Hybridization with a sense PAI-1 cRNA revealed no significant non-specific hybridization (Fig. 5c, $\mathrm{f}$ and i).

\section{Discussion}

Local regulation of corpora lutea function, and the corresponding identification and elucidation of the physiological role of proteins secreted by luteal cells, is an area of increasing research interest. Certainly, secretory products of the corpus luteum must play a role in the regulation of many of the crucial biological processes accompanying its formation, maintenance and regression. Given the pronounced and diverse effects of changes in the extracellular matrix on cell migration, cell proliferation, cell differentiation and gene expression (Getzenberg et al., 1990), one plausible function for secretory (a)

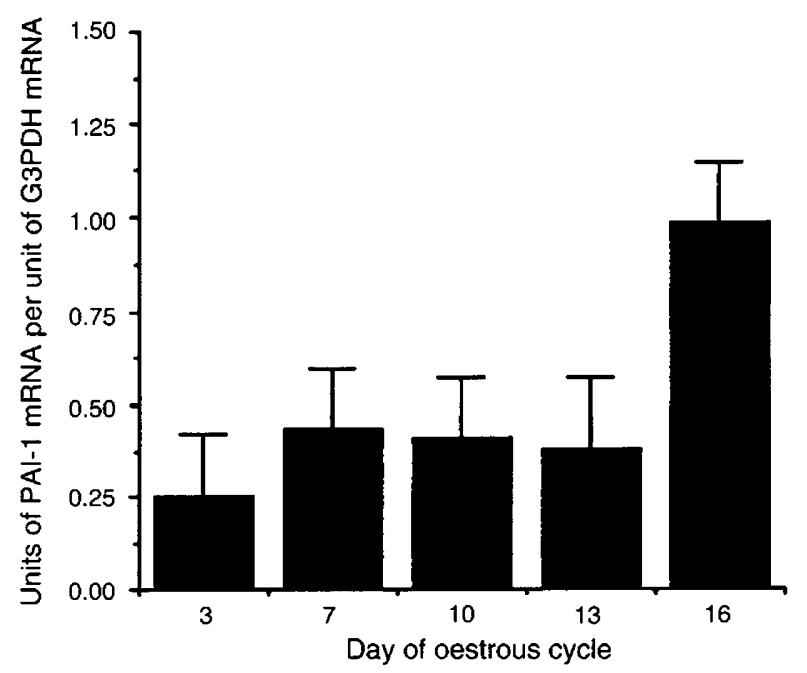

(b)

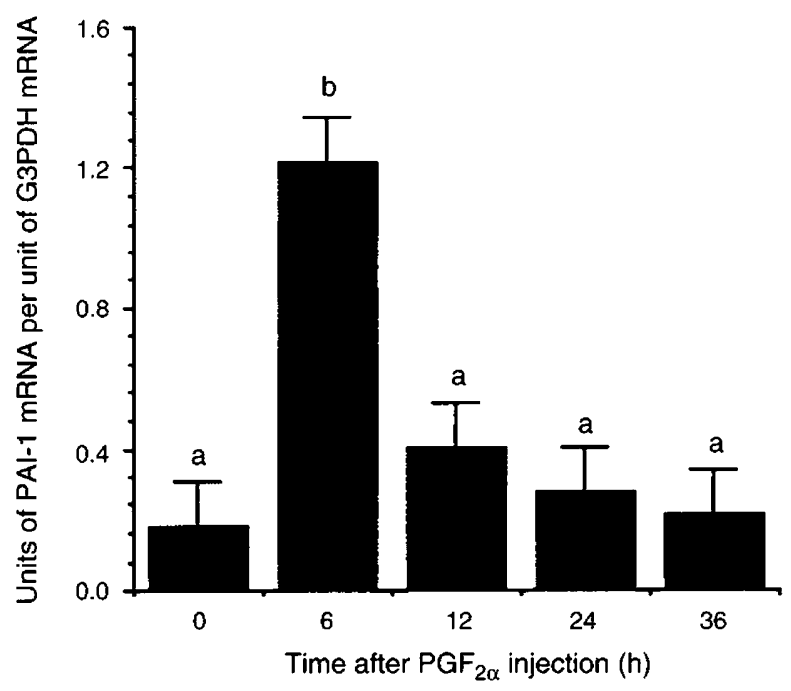

Fig. 4. Quantification of expression of plasminogen activator inhibitor type-1 (PAI-1) mRNA during the luteal phase and during luteolysis induced by prostaglandin $F_{2 u^{\circ}}$ (a) Relative amounts of mRNA encoding PAI-I in corpora lutea at five stages of the oestrous cycle. Total cellular RNA was isolated from corpora lutea collected on days 3,7 , 10, 13 and 16 after oestrus ( $n=4,4,4,3$ and 4, respectively). Amounts of PAI-1 mRNA were determined by dot blot analysis, adjusted relative to the amounts of glyceraldehyde-3-phosphate dehydrogenase (G3PDH) mRNA and expressed as units of PAI-1 mRNA per unit of G3PDH mRNA (mean values \pm seM) $(P=0.06)$. (b) Total cellular RNA was isolated from ovine corpora lutea collected 0 , $6,12,24$ and $36 \mathrm{~h}$ ( $n=4$ each) after $\mathrm{PGF}_{2 \alpha}$ injection on day 10 after oestrus. Amounts of mRNA encoding PAI- 1 were determined by dot blot analysis, adjusted relative to the amounts of G3PDH mRNA and expressed as units of PAI-I mRNA per unit of G3PDH mRNA (mean values $\pm \operatorname{SEM}$ ) ( $\mathrm{a}$ and $\mathrm{b}, P=0.0004$ ).

proteins of the corpus luteum is to regulate the complex process of extracellular matrix remodelling.

In the present studies, one of the major secretory proteins of the ovine corpus luteum was identified as plasminogen 

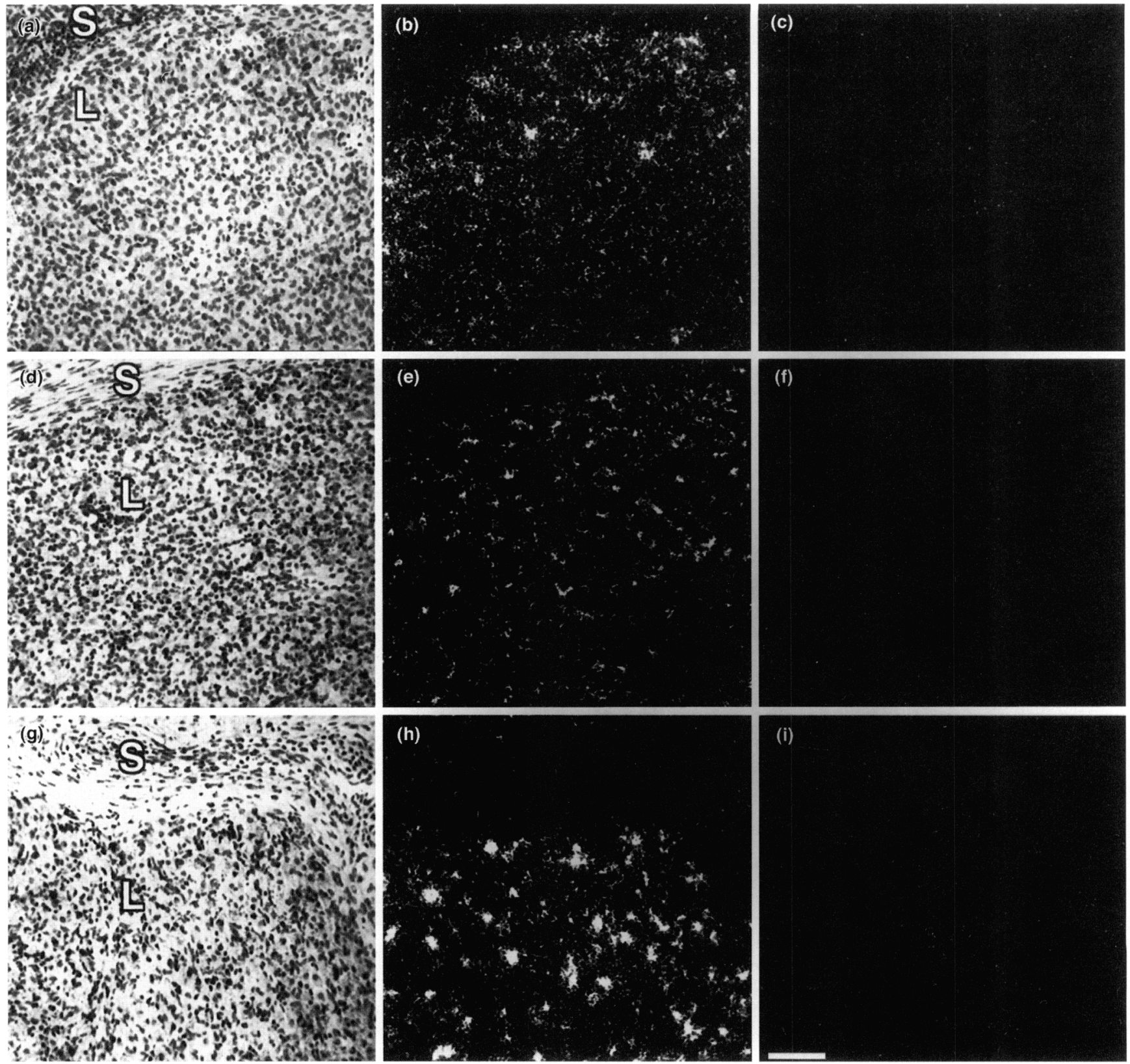

Fig. 5. In situ localization of plasminogen activator inhibitor type-1 (PAI-1) mRNA within ovine corpora lutea. (a) Bright-field micrograph of a section of a day 3 corpus luteum hybridized with an antisense PAI-I cRNA and stained with haematoxylin and eosin. (b) Dark-field micrograph of a section of a day 3 corpus luteum hybridized with an antisense PAI-1 cRNA (same section as in (a)). (c) Dark-field micrograph of adjacent serial section of a day 3 corpus luteum hybridized with a sense (negative control) PAI-1 cRNA. (d) Bright-field micrograph of a section of a corpus luteum on day 10 hybridized with an antisense PAI-I cRNA and stained with haematoxylin and eosin. (e) Dark-field micrograph of a day IO section of a corpus luteum hybridized with an antisense PAI-1 cRNA (same section as in (d)). ( $\mathrm{f}$ ) Dark-field micrograph of adjacent serial section of a day 10 corpus luteum hybridized with a sense (negative control) PAI-I cRNA. (g) Bright-field micrograph of a section of a regressed corpus luteum ( $30 \mathrm{~h}$ after prostaglandin $\mathrm{F}_{2 u}\left(\mathrm{PGF}_{2,1}\right)$ injection on day 10$)$ hybridized with an antisense PAl-1 cRNA and stained with haematoxylin and

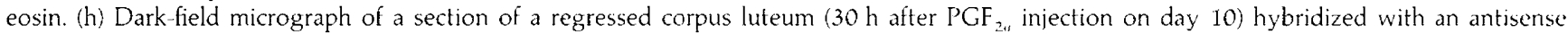
PAl-1 cRNA (same section as in (g)). (i) Dark-field micrograph of adjacent serial section of a regressed corpus luteum ( $30 \mathrm{~h}$ after PGF $2 u$ injection on day 10) hybridized with a sense (negative control) PAI- 1 CRNA $(n=3$ animals tested for corpora lutea on day 3 , day 10 and $30 \mathrm{~h}$ after PGF 2, injection on day 10 (regressed)). L, luteal tissue; S, stroma. Scale bar represents $80 \mu \mathrm{m}$.

activator inhibitor type-1 (PAI-1), a major regulator of extracellular matrix remodelling catalysed by the plasminogen-activator-plasmin system (Cajot et al., 1990). Urokinase binding activity was readily detectable within medium conditioned by ovine luteal cells, and inhibitory activity toward plasminogen activator has been detected previously within medium conditioned by rat (Yi-xun ef al., 1995) and monkey (Qiang et al., 1993) luteal cells. Subsequent 
immunoprecipitation from radiolabelled luteal cell culture medium verified that PAI- 1 is secreted by ovine luteal cells.

The relative molecular mass $(70000)$ of the putative PAI-IuPA complex observed in the uPA binding studies is similar to the reported size of the complex formed by ${ }^{125} \mathrm{IJuPA}$ and PAI-1 from human cerebrospinal fluid (Rao et al., 1993). When analysed under reducing conditions, the predicted relative molecular mass of the complex of PAI-1 $(56000)$ and the catalytic subunit (33000) of uPA (Eaton et al., 1984) is larger than that observed in the present studies. This difference between the observed and predicted mass of the uPA-PAI-I complex may be due partly to the proteolytic cleavage of PAI-1 at its carboxy terminus after complex formation (Rao et al., 1993).

Northern analysis revealed that PAI-1 mRNA is expressed by ovine corpora lutea. The bovine cDNA encoding PAI-I used hybridized predominantly to a single mRNA species of approximately $3.6 \mathrm{~kb}$. The size of the ovine PAI-1 mRNA transcript detected is similar to the reported size of the predominant PAI-1 transcript expressed in human placenta and uterus (Lucore et al., 1988) and in rat gonadal tissues (Nargolwalla et al., 1990; Liu et al., 1996). A second smaller transcript $(2.4 \mathrm{~kb})$, which arises by the use of an alternative polyadenylation signal (Loskutoff et al., 1987), is also expressed in human tissues (Lucore et al., 1988). However, a similar PAI-1 transcript was not detected in the present studies, even with increased exposure times.

mRNA encoding PAI-1 was specifically localized within corpora lutea that were developing (day 3), mature (day 10) and regressing ( $30 \mathrm{~h}$ after $\mathrm{PGF}_{2 \alpha}$ injection on day 10) by in situ hybridization. Particularly within corpora lutea on day 10, the mRNA appeared to be concentrated within a subpopulation of luteal cells, but we were unable to determine the exact identity of the luteal cells expressing PAI-1 with this procedure. Because PAI-I is characteristically expressed by cultured endothelial cells (Hart and Rehemtulla, 1988), it is likely that endothelial cells may contribute to PAI-I expression within the corpora lutea. Bacharach et al. (1992), in a study on angiogenesis in the rat, detected mRNA encoding PAI-I primarily in those cells in the vicinity of capillaries that expressed uPA. Based on this observation, they proposed a potential interaction between endothelial cells and neighbouring cells during neovascularization. Perhaps the local expression of PAI- 1 by ovine luteal cells similarly restricts the greater proteolysis accompanying neovascularization within the corpus luteum. mRNA encoding PAI-I expression has also been observed in human granulosa-luteal cells (Piquette et al., 1993) and in rat corpora lutea (Bacharach et al., 1992; Liu et al., 1996). During pseudopregnancy in rats, the amount of mRNA encoding PAI-I has increased by day 10, before the onset of luteolysis (Liu et al, 1996). In the present studies, relative concentrations of ovine mRNA encoding PAI-1 were not significantly different during the luteal phase but tended to be higher within regressing corpora lutea on day 16. However, during $\mathrm{PGF}_{2 u}$-induced luteal regression, a transient increase in expression of mRNA encoding PAI- 1 was observed $6 \mathrm{~h}$ after injection. The lack of a significant increase within corpora lutea on day 16 can probably be attributed to heterogeneity in the onset or stage of luteolysis in these animals.
The physiological basis or significance of the transient increase in PAI-1 mRNA during luteolysis is unclear. Expression of PAI-1 mRNA and protein is characteristically increased in several cell lines by treatment with phorbol esters (reviewed by Andreasen et al., 1990) and an enhancer element mediating phorbol ester responsiveness of the human gene for PAI-1 has been described (Knudsen et al., 1994). Binding of $\mathrm{PGF}_{2 u}$ to its receptor on large luteal cells results in activation of protein kinase C (Wiltbank et al., 1991). Thus, the increase in PAI-1 mRNA observed during luteolysis may be mediated by this mechanism.

The precise physiological role of PAI-1, particularly in the reproductive system, remains an enigma. PAI-I-deficient mice have been generated by gene targeting procedures (Carmeliet et al., 1993). Although it has been proposed that PAI-1 plays a regulatory role in ovulation and the subsequent formation of corpora lutea ( $\mathrm{Ny}$ et al., 1993), and in implantation (Feinberg et al., 1989), PAI-1-deficient mice are fertile and exhibit no obvious reproductive abnormalities (Carmeliet et al., 1993). Compensatory mechanisms or biological redundancy due to other plasminogen activator inhibitors may account for the apparently normal phenotype of the PAI- 1 deficient mice.

In summary, we conclude that PAI- 1 is a major secretory protein of the ovine corpus luteum. Although the precise physiological significance of PAI-1 expression within the ovine corpus luteum is not yet known, PAI-1 probably plays a key role in the regulation of the extensive extracellular matrix remodelling that occurs during the luteal phase.

Contribution from the Missouri Agricultural Experiment Station. Journal Series Number 12,503. This research was supported in part by NIH HD21896 to R. M. Roberts and a grant from the MU Research Board to M. F. Smith and R. M. Roberts.

\section{References}

Andreasen PA, Georg B, Lund LR, Riccio A and Stacy SN (1990) Plasminogen activator inhibitors: hormonally regulated serpins Molecular and Cellular Endocrinology 68 I-19

Bacharach E, Itin A and Kehset E (1992) In vivo patterns of expression of urokinase and its inhibitor PAI-1 suggest a concerted role in regulating physiological angiogenesis Proceedings of the National Academy of Science USA 89 10 686-10 690

Cajot JF, Bamat J, Bergonzelli GE, Kruithof EKO, Medcalf RL, Testuz J and Sordat B (1990) Plasminogen-activator inhibitor type 1 is a potent natural inhibitor of extracellular matrix degradation by fibrosarcoma and colon carcinoma cells Proceedings of the National Academy of Science USA 87 6939-6943

Carmeliet P, Kieckens L, Schoonjans L, Ream B, Van Nuffelen A, Prendergast G, Cole M, Bronson R, Collen D and Mulligan RC (1993) Plasminogen activator inhibitor-1 gene-deficient mice: Generation by homologous recombination and characterization Journal of Clinical Investigation 92 2746-2755

Chesselet MF (1990) In situ Hybridization Histochemistry p. 203 CRC Press, Boca Raton

Chirgwin JM, Przybyla AE, Macdonald RJ and Rutter WJ (1979) Isolation of biologically active ribonucleic acid from sources enriched in ribonuclease Biochemistry 18 5294-5299

Chun SY, Popliker M, Reich R and Tsafriri A (1992) Localization and preovulatory expression of plasminogen activator inhibitor type-I and tissue inhibitor of metalloproteinase type-1 mRNAs in the rat ovary Biology of Reproduction 47 245-253

Eaton DL, Scott RW and Baker JB (1984) Purification of human fibroblast urokinase proenzyme and analysis of its regulation by proteases and protease nexin Journal of Biological Chemistry $2596241-6247$ 
Espey LL and Lipner H (1994) Ovulation. In The Physiology of Reproduction pp 725-780 Eds E Knobil and JD Neill. Raven Press, New York

Feinberg RF, Kao LC, Haimowitz JE, Queenan JT, Jr, Wun TC, Strauss JF, III and Kliman HJ (1989) Plasminogen activator inhibitors types 1 and 2 in human trophoblasts Laboratory Investigation $6120-26$

Fitz TA, Mayan MH, Sawyer HR and Niswender GD (1982) Characterization of two steroidogenic cell types in the ovine corpus luteum Biology of Reproduction 27 703-711

Getzenberg RH, Pienta KJ and Coffey DS (1990) The tissue matrix: Cell dynamics and hormone action Endocrine Reviews 11 399-417

Hart DA and Rehemtulla A (1988) Plasminogen activators and their inhibitors: Regulators of extracellular proteolysis and cell function Comparative Biochemistry and Physiology 90B 691-708

Keisler DH and Keisler LW (1989) Formation and function of GnRH induced subnormal corpora lutea in cyclic ewes journal of Reproduction and Fertility 87 265-273

Knudsen $\mathrm{H}$, Olesen T, Riccio A, Ungaro P, Christensen $\mathrm{L}$ and Andreasen PA (1994) A common response element mediates differential effects of phorbol esters and forskolin on type-1 plasminogen activator inhibitor gene expression in human breast carcinoma cells European Journal of Biochemistry $\mathbf{2 2 0}$ 63-74

Li J and Roberts RM (1994) Interferon- $\tau$ and interferon $\alpha$ interact with the same receptors in bovine endometrium: use of a readily iodinatable form of interferon $\tau$ for binding studies Journal of Biological Chemistry 269 $13544-13550$

Liu K, Brandstrom A, Liu Y, Ny T and Selstam G (1996) Coordinated expression of tissue-type plasminogen activator and plasminogen activator inhibitor type 1 during corpus luteum formation and luteolysis in the adult pseudopregnant rat Endocrinology 137 2126-2132

Loskutoff DJ, Linders M, Keijer J, Veerman H, van Heerikhuizen $H$ and Pannekoek $\mathrm{H}$ (1987) Structure of the human plasminogen activator inhibitor 1 gene: nonrandom distribution of introns Biochemistry 26 3763-3768

Lucore CL, Fujii S, Wun TC, Sobel BE and Billadello JJ (1988) Regulation of the expression of type 1 plasminogen activator inhibitor in Hep G2 cells by epidermal growth factor Journal of Biological Chemistry 263 15845-15848

Mignatti P, Robbins E and Rifkin DB (1986) Tumor invasion through the human amniotic membrane: Requirement for a proteinase cascade Cell 47 487-498

Mimuro J, Sawdey M, Hattori M and Loskutoff DJ (1989) cDNA for bovine type I plasminogen activator inhibitor Nucleic Acids Research 178872

Nargolwalla C, McCabe D and Fritz IB (1990) Modulation of levels of messenger RNA for tissue type plasminogen activator in rat Sertoli cells, and levels of messenger RNA for plasminogen activator inhibitor in testis peritubular cells Molecular and Cellular Endocrinology 70 73-80

Ny T, Peng XR and Ohlsson M (1993) Hormonal regulation of the fibrinolytic components in the ovary Thrombosis Research 71 1-45

Peng XR, Hsueh AJW and Ny T (1993) Transient and cell specific expression of tissue type plasminogen activator and plasminogen activator inhibitor type 1 results in controlled and directed proteolysis during gonadotropin-induced ovulation European Journal of Biochemistry 214 147-156

Piquette GN, Crabtree ME, El-Danasouri I, Milki A and Lake-Polan ML (1993) Regulation of plasminogen activator inhibitor- 1 and-2 messenger ribonucleic acid levels in human cumulus and granulosa-luteal cells Journal of Clinical Endocrinology and Metabolism 76 518-523
Qiang F, Kui L, Zhao-yuan H, Ru-jin Z, Sahng Y and Yi-xun L (1993) The possible involvement of tissue type plasminogen activator in luteolysis of rhesus monkey Human Reproduction 8 1640-1644

Rao JS, Chen M and Festoff BW (1993) Plasminogen activator inhibitor 1, the primary regulator of fibrinolysis, in normal human cerebrospinal fluid Journal of Neuroscience Research 34 340-345

Roberts RM, Mathialagan N, Duffy JY and Smith GW (1995) Regulation and regulatory role of proteinase inhibitors Critical Reviews in Eukaryotic Gene Expression 5 385-436

Sambrook J, Fritsch EF and Maniatis T (1989) Molecular Cloning. A Laboratory Manual (2nd Edn). Cold Spring Harbor Laboratory Press, Cold Spring Harbor

Schleef RR, Podor TJ, Dunne E, Mimuro J and Loskutoff DJ (1990) The majority of type I plasminogen activator inhibitor associated with cultured human endothelial cells is located under the cells and is accessible to solution phase tissue type plasminogen activator Journal of Cell Biology 110 155-163

Smith GW, Moor RM and Smith MF (1993) Identification of a $30,000 \mathrm{Mr}$ polypeptide secreted by cultured granulosa cells and luteal tissue as a tissue inhibitor of metalloproteinases Biology of Reproduction 48 125-132

Smith GW, Goetz TL, Anthony RV and Smith MF (1994) Molecular cloning of an ovine ovarian tissue inhibitor of metalloproteinases: Ontogeny of messenger ribonucleic acid expression and in situ localization within preovulatory follicles and luteal tissue Endocrinology 134 344-352

Smith GW, McCrone S, Petersen SL and Smith MF (1995) Expression of messenger ribonucleic acid encoding tissue inhibitor of metalloproteinases-2 within ovine follicles and corpora lutea Endocrinology 136 570-576

Smith GW, Gentry PC, Roberts RM and Smith MF (1996) Ontogeny and regulation of luteinizing hormone receptor messenger ribonucleic acid within the ovine corpus luteum Biology of Reproduction 54 76-83

Smith MF, McIntush EW and Smith GW (1994) Mechanisms associated with corpus luteum development Journal of Animal Science 72 1857-1872

Smith PK, Krohn RI, Hermanson GT, Malia AK, Gartner FH, Provenzano MD, Fujimoto EK, Goeke NM, Olson BJ and Klenk DC (1985) Measurement of protein using bicinchoninic acid Analytical Biochemistry 150 76-85

Thorsen S, Phillips M, Selmer J, Lecander I and Aastedt B (1988) Kinetics of inhibition of tissue type and urokinase type plasminogen activator by plasminogen activator inhibitor type 1 and type 2 European Journal of Biochemistry $175 \quad 33-39$

Tryggvason K, Hoyhtya M and Salo T (1987) Proteolytic degradation of extracellular matrix in tumor invasion Biochemica et Biophysica Acta 907 191-217

Van Mourik JA, Lawrence DA and Loskutoff DJ (1984) Purification of an inhibitor of plasminogen activator (antiactivator) synthesized by endothelial cells Journal of Biological Chemistry 25914 914-14 921

Wiltbank MC, Diskin MG and Niswender GD (1991) Differential actions of second messenger systems in the corpus luteum Journal of Reproduction and Fertility Supplement 43 65-75

Yi-xun L, Ya-xiong C, Fa-wu S and Qiang F (1995) Studies on the role of plasminogen activators and plasminogen activator inhibitor type-1 in rat corpus luteum of pregnancy Biology of Reproduction 53 1131-1138 